\title{
$\mathrm{DRM}$ 시스템에서 초기 샘플링 주파수 옵셋의 영향에 강인한 고속 동기화 방식
}

\author{
정회원 권 기 원 ${ }^{*}$ 종신회원 조 용 수 ${ }^{* * 0}$
}

\section{A High-Speed Synchronization Method Robust to the Effect of Initial SFO in DRM Systems}

\author{
Ki Won, Kwon ${ }^{*}$ Regular Member, Yong Soo Cho ${ }^{* * \circ}$ Lifelong Member \\ 요 약
}

본 논문에서는 DRM(Digital Radio Mondiale) 수신기를 위한 고속 동기화 방식을 제안한다. 제안하는 방식에서 는 DRM 수신기에서 요구하는 고속 수신 성능을 만족시키기 위해 기존 동기화 방식에서 수행하는 초기 샘플링 주파수 동기과정을 생략하고 정수배 주파수(Integer Frequency) 동기 및 프레임(Frame) 검출을 수행한 후, 추적 (Tracking) 과정에서 샘플링 주파수 동기를 수행한다. 샘플링 주파수 옵셋(Sampling Frequency Offset)이 포함된 OFDM(Orthogonal Frequency Division Multiplexing) 복조 심볼로부터 프레임 옵셋을 추정하기 위해 참조셀 (Reference cell)에 상관 기반 추정 알고리즘을 적용하고 그 성능을 분석하여 샘플링 주파수 옵셋에 강한 알고리 즘을 선정한다. 제안된 구조는 DRM 수신 신호에 샘플링 주파수 옵셋이 존재하는 경우에도 초기 샘플링 주파수 동기화 과정에 소요되는 시간을 단축할 수 있으며, 참조셀간 차동 상관(Inter-cell Differential Correlation) 기법을 사용할 경우 초기 샘플링 주파수 옵셋의 영향에 강인함을 프레임 검출 모의실험을 통해 확인한다.

Key Words : DRM, Frame Detector, SFO, Synchronization

\section{ABSTRACT}

In this paper, we propose a high-speed synchronization method for Digital Radio Mondiale (DRM) receivers. In order to satisfy the high-speed synchronization requirement of DRM receivers, the proposed method eliminate the initial sampling frequency synchronization process in conventional synchronization methods. In the proposed method, sampling frequency tracking is performed after integer frequency synchronization and frame synchronization. Different correlation algorithms are applied to detect the first frame of the Orthogonal Frequency Division Multiplexing (OFDM) demodulation symbol with sampling frequency offset (SFO). A frame detection algorithm that is robust to SFO is selected based on the performance analysis and simulation. Simulation results show that the proposed method reduces the time spent for initial sampling frequency synchronization even if SFO is present in the DRM signal. In addition, it is verify that inter-cell differential correlation used between reference cells is roubst to the effect of initial SFO.

\footnotetext{
※ 본 연구는 방송통신위원회의 차세대통신네트워크원천기술개발사업의 연구결과로 수행되었음(KCA-2011-09913-04002)

* 전자부품연구원 모바일단말연구센터 (kwonkw@keti.re.kr), ** 중앙대학교 디지털통신연구실 (yscho@cau.ac.kr), $\left({ }^{\circ}:\right.$ 교신저자)

논문번호 : KICS2011-04-201, 접수일자 : 2011년 4월 28일, 최종논문접수일자: 2011년 9월 28일
} 


\section{I. 서 론}

$\mathrm{DRM}$ (Digital Radio Mondiale)은 $30 \mathrm{MHz}$ 이하 장 파, 중파, 단파 방송 주파수 대역에서의 음악, 동영상, 데이터 등의 다양한 멀티미디어 서비스를 위해 개발 된 디지털 라디오 방송 규격이다 ${ }^{[1]}$. DRM이 사용하는 주파수 대역은 전파 특성상 넓은 지역을 커버할 수 있 어 방송 분야에서 전 세계적으로 큰 관심을 받아왔다. 현재 유럽, 중국 등에서 DRM 서비스가 이루어지고 있 으며, 최근에는 인도 러시아 등에서 서비스 도입이 확 정되어 관련 인프라 구축이 진행중에 있어 향후 방송 범위가 전 세계적으로 크게 확대될 것으로 전망된다.

DRM 방송 서비스를 이용하기 위해서는 전원이 인 가된 DRM 수신기가 RF 방송신호를 수신하여 기저대 역 디지털 신호로 변환한 후, 동기화, 등화, 복호화 (decoding), 파싱(parsing)등의 전처리 과정을 수행해 야 한다. 따라서 사용자가 DRM 수신기의 전원을 인 가한 시점부터 음성 또는 데이터 서비스가 제공될 때 까지 시간지연이 불가피하게 발생하게 된다. 아날로그 방식의 수신기에서는 발생되지 않는 이와 같은 시간 지연은 사용자가 수신기(특히, 자동차, 모바일기기에 탑재되는 수신기)의 성능을 판단하게 되는 핵심 요소 의 하나로 DRM 수신기 설계자는 반드시 수신기의 시 간지연을 설계 파라미터로 고려해야 한다. DRM 수신 기의 동기화는 심볼 시간, 반송파 주파수, 샘플링 주 파수와 관련된 여러 단계의 동기화로 구성되어 있어 복호화나 데이터 파싱 등의 다른 디지털 전처리 과정 에 비해 알고리즘 측면에서 처리 속도를 향상시킬 수 있는 가능성이 있다 ${ }^{[2]}$. 동기화를 위하여 DRM 규격에 서는 OFDM 파일럿과 동일한 기능을 하는 참조셀 (Reference Cell)을 사용하며 OFDM 파일럿 기반의 기존 초기 동기화 기법 중 DRM 규격에 적합한 기법 을 선정하거나 DRM 규격에 적합하게 변형하여 효율 적인 초기 동기화를 이룰 수 있다.

DRM 동기화를 위한 방식으로 시간영역에서 심볼 시간 동기, 소수배 주파수 동기, 샘플링 주파수 동기 를 각각 순차적으로 수행하고 주파수 영역에서 정수 배 주파수 동기 및 프레임 검출을 수행하는 초기 동기 화 방식이 제안되었다 ${ }^{[3]}$. 그러나 이 방식은 초기 샘플 링 주파수 동기를 위한 샘플링 주파수 옵셋 추정 과정 에서 다수의 OFDM 심볼을 이용해야 하므로 고속 동 기화에 적합하지 않다. 또 다른 동기화 방식으로는 동 일한 신호로부터 두 가지 이상의 동기화 파라미터를 분리하여 동시에 추정하는 방식이 제안되었다. 이 방 식에서는 심볼 시간과 반송파 주파수 옵셋 또는 반송
파 주파수와 샘플링 주파수 옵셋 동기를 동시에 추정 한다 ${ }^{[4,5]}$. 이 방식을 병렬처리 구조로 구현하면 초기 동기화에 필요한 추정 단계를 줄일수 있다. 그러나 이 방식을 위해 제안된 기존 추정 알고리즘들은 규칙적 인 훈련심볼이나 파일럿 기반의 버스트 모드(Burst Mode) OFDM 통신시스템의 주파수 동기에 기반을 두고 있어 DRM과 같은 불규칙적인 파일럿 기반의 연 속 모드(Continuous Mode) 방송시스템에 적합하지 않다.

본 논문에서는 이와 같은 DRM 수신기의 초기 고 속 동기화 문제를 해결하기 위해 심볼 시간 동기화 이 후에 수행하는 동기화 구조를 제안한다. 제안하는 구 조는 DRM 수신기에서 시간 지연을 감소시키기 위해 동기성능에 큰 영향을 주지 않는 초기 샘플링 주파수 동기를 생략하면서도 샘플링 주파수 옵셋의 영향을 크게 받지 않는 프레임 검출 기법을 비교 선정한다. 본 논문의 나머지 구성은 다음과 같다. ㅍㅓㅓ에서는 $\mathrm{DRM}$ 의 개요를 기술하며, 피절에서는 기존 DRM 동 기화 방식과 고속 동기화 방식의 필요성을 설명한다. $\mathrm{IV}$ 절에서는 제안된 DRM 동기 방식을 설명하고, 제 $\mathrm{V}$ 절에서 모의실험을 통해 제안된 방식의 성능을 확 인 후, VI절에서 결론을 내린다.

\section{DRM 개요}

DRM은 OFDM 변조 방식을 사용하기 때문에 주 파수 효율이 높고, 주파수 선택적 페이딩에 쉽게 대처 할 수 있는 반면에 동기성능에 따라 전체적인 수신 성 능이 민감하게 반응하는 단점이 있다. DRM의 물리계 층은 $\mathrm{AM}$ 주파수 대역의 다양한 전송 환경에서 고품 질의 오디오 서비스를 제공하기 위해서 $9 \sim 10 \mathrm{kHz}$ 의 $\mathrm{AM}$ 대역폭에서 $2 \mathrm{bits} / \mathrm{s} / \mathrm{Hz}$ 이상의 스펙트럼 효율을 제공할 수 있도록 설계되었다. 전송 프레임 구조는 수 신기에서 요구되는 채널 정보와 서비스 관련된 정보 를 지닌 FAC(Fast Access Channel), 오디오와 데이터 를 포함하는 MSC(Main Service Channel), MSC의 채널 부호화 파라미터, 오디오 및 데이터 신호의 다중화 구조 전체를 지닌 $\mathrm{SDC}$ (Service Description Channel) 로 구성 된다. 전송모드 $\mathrm{A} \sim \mathrm{D}$ 의 경우에 $400 \mathrm{~ms}$ 프레 임(Frame) 3개로 구성된 슈퍼 프레임(Super Frame) 은 $1200 \mathrm{~ms}$ 길이를 가지며, $\mathrm{DRM}+$ 인 전송모드 $\mathrm{E}$ 의 경우에 $100 \mathrm{~ms}$ 프레임 4 개로 구성된 슈퍼 프레임은 $400 \mathrm{~ms}$ 길이를 가진다. 그림 1 은 슈퍼프레임의 구조 를 나타낸다. 각 모드별로 $15 \sim 24$ 개의 OFDM 심볼이 한 프레임을 구성하며 매 슈퍼프레임의 맨 앞의 2 3 


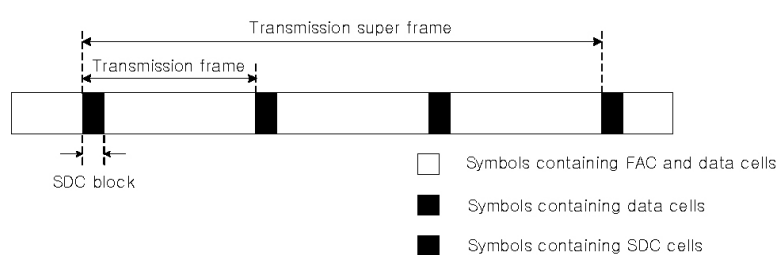

그림 1. DRM 전송 슈퍼 프레임 구조

개 $\mathrm{OFDM}$ 심볼에 $\mathrm{SDC}$ 가 전송되고, 그 외의 $\mathrm{OFDM}$ 심볼에는 $\mathrm{MSC}$ 와 $\mathrm{FAC}$ 가 함께 전송된다. $\mathrm{DRM}$ 수신 을 위해서는 프레임 시작을 검출하는 프레임 동기를 수행해야 한다. 그림 2는 DRM 프레임 심볼 구조를 보여준다.

$\mathrm{DRM}$ 서비스의 주파수 특성상, 지상파 또는 상층 파 전송에 따라 다양한 환경에 효과적으로 대응하기 위해 5 가지 전송 모드를 정의하였으며, 각 모드에 대 한 OFDM 심볼 파라미터는 표 1 과 같다. 전송모드 A $\sim \mathrm{D}$ 는 $30 \mathrm{MHz}$ 이하 대역에서 $\mathrm{AM}$ 의 디지털 라디오 를 지원하며, 전송모드 $\mathrm{E}$ 는 $30 \sim 174 \mathrm{MHz}$ 대역에서 디지털 라디오를 지원한다. $30 \mathrm{MHz}$ 대역 이하에서 전송모드 $\mathrm{A}$ 가 가장 양호한 전파환경에 해당하고, 전 송모드 $\mathrm{D}$ 의 경우 가장 열악한 전파 환경에 해당된다. $30 \sim 174 \mathrm{MHz}$ 대역에는 모드 $\mathrm{E}$ 하나만 선택할 수 있 으며, 시간-주파수 선택적 페이딩 채널에 강인하게 설 계되었다. 또한 각 모드에 따라 $4.5 / 5 / 9 / 10 / 18 / 20$ $100 \mathrm{kHz}$ 의 다양한 주파수 점유 대역폭(Spectrum Occupancy)에서 동작 가능하며, 이 점유 대역폭에 대 한 정보는 $\mathrm{FAC}$ 를 통하여 전송된다. 그러므로 기존의 동기화 과정에서 중심주파수로부터 $4.5 \mathrm{kHz}$ 대역폭에 서 $\mathrm{FAC}$ 가 오류 없이 복호된 경우, $\mathrm{FAC}$ 로부터 점유 대역폭에 대한 정보를 획득한 후 지정된 점유 대역폭 에 대한 채널추정이 수행된다. DRM에서는 동기 및 채널추정과 같은 작업을 수행하기 위해 참조셀을 정

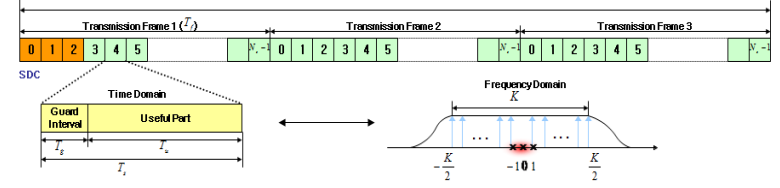

그림 2. DRM 전송 프레임 및 심볼 구조

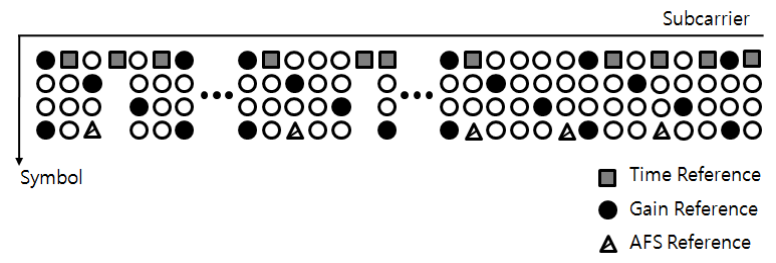

그림 3. 참조셀 구조
표 1. 모드에 따른 OFDM 심볼파라미터

\begin{tabular}{|c|c|c|c|c|c|}
\hline 항목 & $\mathrm{A}$ & $\mathrm{B}$ & $\mathrm{C}$ & $\mathrm{D}$ & $\mathrm{E}$ \\
\hline $\mathrm{T}(\mu \mathrm{s})$ & $83^{1 / 3}$ & $83^{1 / 3}$ & $83^{1 / 3}$ & $83^{1 / 3}$ & $83^{1 / 3}$ \\
\hline $\begin{array}{c}\text { 유효심볼 } \\
\text { 길이(ms) }\end{array}$ & 24 & $21^{1 / 3}$ & $14^{2 / 3}$ & $9^{1 / 3}$ & $2^{1 / 4}$ \\
\hline $\begin{array}{c}\text { 보호구간 } \\
\text { 길이(ms) }\end{array}$ & $2^{2 / 3}$ & $5^{1 / 3}$ & $5^{1 / 3}$ & $7^{1 / 3}$ & $0^{1 / 4}$ \\
\hline $\begin{array}{c}\text { 보호구간 } \\
\text { /유효심볼 }\end{array}$ & $1 / 9$ & $1 / 4$ & $4 / 11$ & $11 / 14$ & $1 / 9$ \\
\hline $\begin{array}{c}\text { 전체심볼 } \\
\text { 길이(ms) }\end{array}$ & $26^{2 / 3}$ & $26^{2 / 3}$ & 20 & $16^{2 / 3}$ & $2^{1 / 2}$ \\
\hline $\begin{array}{c}\text { 프레임 } \\
\text { 길이(ms) }\end{array}$ & 400 & 100 \\
\hline
\end{tabular}

의하고 있다. 그림 3 은 3 가지 종류의 참조셀을 보여준 다. 여기서 주파수 참조셀(Frequency Reference Cell) 은 매 OFDM 심볼마다 $750,2250,3000 \mathrm{~Hz}$ 에 해당 하는 부반송파에 연속적으로 존재하며 주파수 동기를 수행하는데 사용된다. 시간 참조셀(Time Reference Cell)는 매 전송 프레임의 첫번째 OFDM 심볼에만 존 재하며 주파수 동기와 프레임 동기를 수행하는데 사용 된다. 이득 참조셀(Gain Reference Cell)은 매 OFDM 심볼에 분산되어 존재하며 채널 추정에 사용된다. 모 든 참조셀은 $\sqrt{2}$ 의 계수를 가지며, 맨 가장자리에 있 는 이득 참조셀은 2 의 계수를 갖는다 ${ }^{[1,6]}$.

\section{III. 기존 DRM 동기화 방식}

기존 DRM 동기화 방식을 요약하면 다음과 같다. 동기화를 포함한 전체 DRM 수신과정은 그림 4에 주 어여 있다. 먼저 $\mathrm{DRM}$ 의 서로 다른 5 가지 전송모드 검출을 수행한다. 전송모드 검출은 모드별로 보호길이 구간과 유효심볼 구간의 동일한 신호의 상관을 구하 여 검출한다. 전송모드가 결정되면 다중 점유 대역폭 과 상관없이 중심 주파수로부터 $4.5 \mathrm{kHz}$ 범위에서 위 치한 참조셀들을 이용하여 다음 동기화 과정을 수행 한다. 대략적인 심볼 시간 동기(Corse Symbol Timing Synchronization)를 맞추고 소수배 주파수 옵셋 (Fractional Carrier Frequency Offset)을 추정해 보상 한다. 그 후, 샘플링 주파수 옵셋을 추정 및 보상한 후, FFT를 통해 주파수 영역 신호로 변환하고 정수배 주 파수 옵셋 추정과 프레임 검출을 수행한다. 위와 같이 초기 동기 과정을 수행한 다음에는 계속해서 타이밍 옵셋과 주파수 옵셋을 추적한다 ${ }^{[3,5]}$.

$\mathrm{DRM}$ 송/수신단의 오실레이터 주파수 오차에 의해 


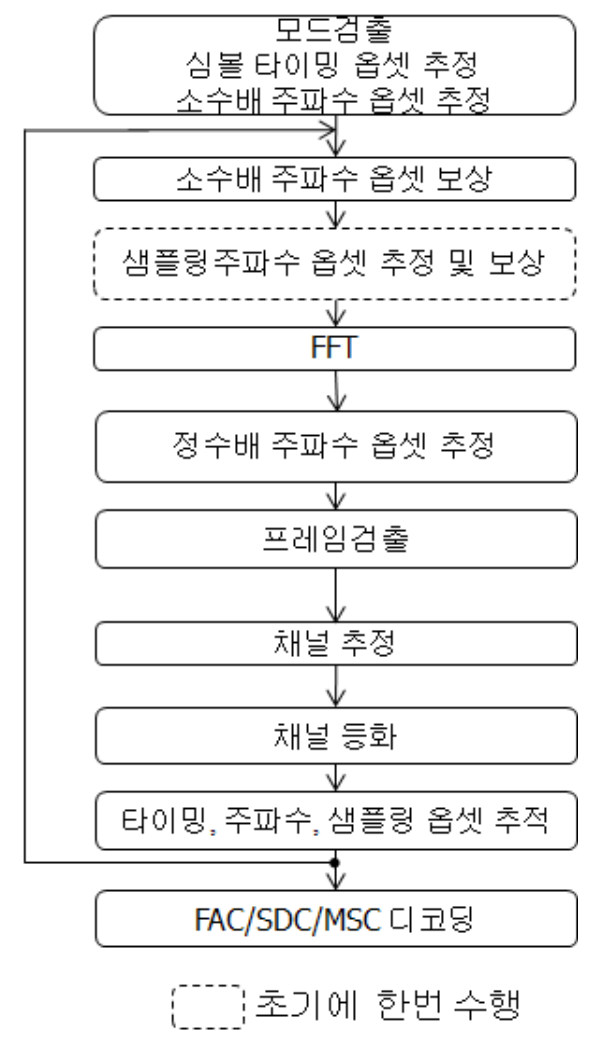

그림 4. 기존 방식의 $\mathrm{DRM}$ 동기화 과정

발생하는 샘플링 주파수 옵셋으로 OFDM 심볼 타이 밍의 드리프트(Drift) 현상이 발생한다. 이것은 FFT 윈도우 시작점 변경 및 심볼간 간섭과 반송파간 간섭 을 야기하고 안정적인 DRM 프레임 동기를 방해하여, 그 결과 수신단 전체의 성능열화를 발생시킨다 ${ }^{[7-9]}$. 또 한, 기존 다양한 DRM 수신기에서는 저가의 오실레이 터 사용으로 인해 발생하는 초기 샘플링 주파수 옵셋 을 추정하고 보상하기 위해 초기 샘플링 주파수 동기 를 수행한다. 하지만 샘플링 주파수 동기를 위해서는 샘플링 주파수 옵셋을 추정하고 보상하는 과정이 필 요함으로 초기 동기화 과정이 길어진다. 이것은 결국 청취자들에게 제공되는 서비스 시작 시간이 늦어짐을 의미함으로 고속 동기화 기법은 수신기 성능의 중요 한 요소로 인식되고 있다.

\section{IV. 제안된 DRM 동기화 방식}

\section{1 초기 샘플링 주파수 옵셋 추정 및 보상을 제} 거한 고속 동기화 구조 설계

본 논문에서는 초기 고속 동기화를 위해 데이터 수 신 성능에 미치는 영향이 적은 초기 샘플링 주파수 옵 셋 추정과 보상 부분을 생략하는 새로운 동기화 방식 을 제안하며, 샘플링 주파수 옵셋이 존재하는 상황에
서 정수배 주파수 옵셋 추정과 프레임 검출을 위해 어 떤 추정 기법을 사용해야 하는지를 비교 선정한다.

샘플링 주파수 옵셋은 다량의 심볼이 누적될 경우 성능 열화를 초래함으로, 제안하는 방식에서는 동기화 초기에 이 부분을 제거하여 빠른 동기화를 수행할 수 있도록 한다. 그림 5 는 제안된 고속 동기화 구조를 보 여준다. 기본적으로 DRM 수신기에서는 샘플링 주파 수 옵셋의 허용 범위를 제조사별로 규정하고 있으며, DRM 수신기 설계자는 이 허용 범위를 만족시키는 오 실레이터를 선정하여 수신기를 설계할 수 있다. 그러 나 규격을 정확히 만족시키는 고정밀, 고정확도를 갖 는 고가의 오실레이터를 사용하게 되면 단말기 가격 상승 요인으로 작용함으로 실제 단말기 단가를 고려 하여 저가의 오실레이터를 사용하며 이로 인해 수신 신호에는 샘플링 주파수 옵셋이 발생된다. 따라서 이 경우에는 샘플링 주파수 동기가 필요하다. 샘플링 주 파수 옵셋을 추정하기 위해서는 최소한으로 관찰해야 하는 심볼이 필요하며 추정된 옵셋을 보상해야 한다. 이 과정으로 인해 동기화 시간이 소요되게 된다. 예를 들면, 수신기 개발시 요구되어지는 샘플링 주파수 옵 셋의 값이 $10 \mathrm{ppm}$ 이고, 현재 추정된 샘플링 주파수 옵셋이 약 $50 \mathrm{ppm}$ 인 경우, 요구되는 $10 \mathrm{ppm}$ 만큼 보 상을 하기 위해 기존방식은 약 35 여개의 심볼을 관찰 하고 보상하는 과정을 반드시 수행하여야 성능이 보 장될 수 있다 ${ }^{[9]}$. 제안된 기법은 초기 샘플링 주파수 옵 셋 추정과 보상 과정을 초기에 수행하지 않으므로 이 로 인한 동기화 속도를 높일 수 있다. 샘플링 주파수

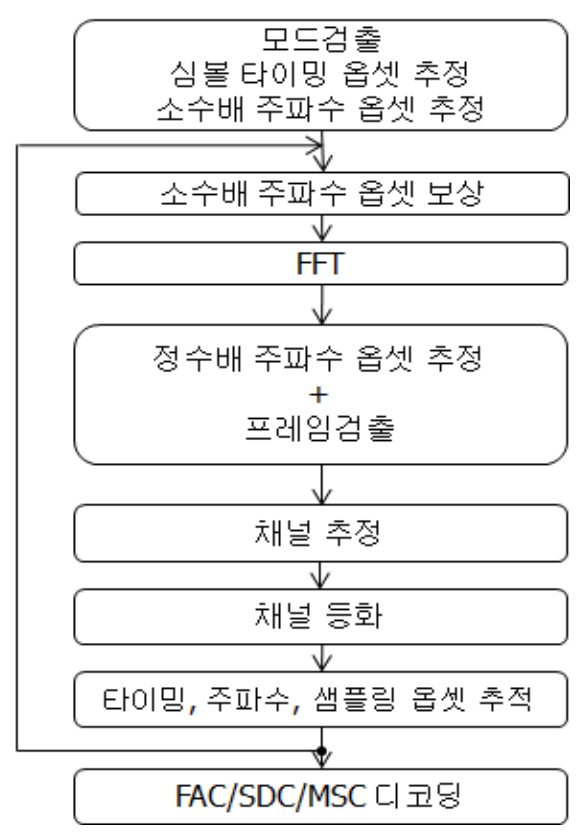

그림 5. 제안된 DRM 동기화 기법 
의 초기 추정과 보상을 생략하였으므로 FFT 이후에 OFDM 심볼에는 샘플링 주파수 옵셋이 포함되고, 이 로 인해 이후의 동기화 성능이 열화 될 수 있다. 따라 서 샘플링 주피수 옵셋의 영향을 감소시킬 수 있는 정 수배 주파수 옵셋과 프레임 검출 기법을 사용하여 동 기화 성능의 열화를 방지해야 한다.

위와 같이 초기 동기 과정을 수행한 다음에는 계속 적으로 심볼 타이밍 옵셋과 반송파 주파수 옵셋, 샘플 링 주파수 옵셋을 추적하고 보상하는 과정을 수행한 다. 그림 6은 제안된 고속 동기화 기법의 구조도를 보 여준다.

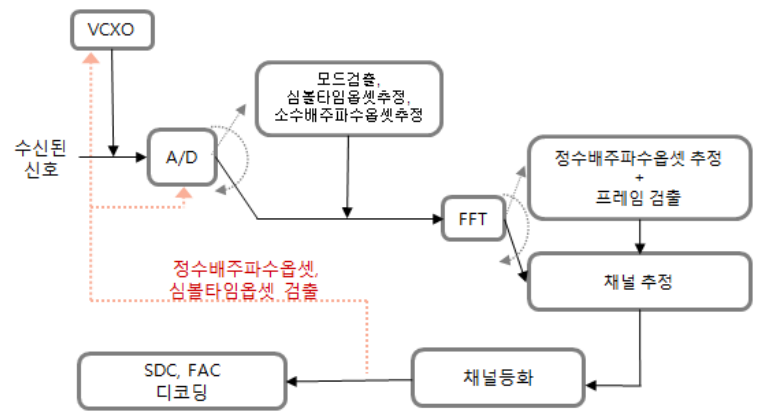

그림 6. 제안된 고속 동기화 기법 구조도

\section{2 샘플링 주파수 옵셋의 영향에 강인한 프레임 검출 방식 분석}

$\mathrm{DRM}$ 수신기의 초기 고속 동기화를 위해 초기 샘 플링 주파수 옵셋의 추정과 보상 과정을 생략하고 FFT 이후에 정수배 반송파 주파수 옵셋 추정과 프레 임 검출을 수행하는 경우, 그 성능은 초기 샘플링 주 파수 옵셋에 의해 영향을 받으며, 영향의 정도는 사용 하는 알고리즘의 특성에 따라 좌우된다. 따라서 보다 정확한 정수배 주파수 옵셋 추정과 프레임 검출을 위 해서는 초기 샘플링 주파수 옵셋의 영향에 강한 알고 리즘을 선정하여 사용하는 것이 중요하다. 본 논문에 서는 FFT 이후의 주파수 영역 OFDM 심볼에 적용하 기 적합한 참조셀 기반의 두 가지 상관 기법의 특성을 비교 분석한다. 샘플링 주파수 옵셋의 영향은 정수배 주파수 옵셋과 프레임 검출 과정에 동일하게 영향을 미치므로 본절에서는 프레임 검출 과정만을 살펴보도 록 한다.

참조셀 기반의 상관 기법으로 가장 간단한 기법은 참조셀과 수신된 신호의 상관을 이용하는 방식이다. 이상적인 심볼 타이밍 동기 가정하에 샘플링 주파수 옵셋의 영향을 받는 FFT 이후의 $l$ 번째 OFDM 수신 심볼은 다음과 같이 표현된다 ${ }^{[9,11]}$.

$$
\begin{aligned}
R_{l}(k)= & \alpha\left(\xi \cdot N_{s} \cdot l\right) \cdot e^{j \pi \phi_{k}} \cdot e^{j 2 \pi\left(\xi \cdot N_{s} \cdot l\right)} \\
& \cdot e^{j 2 \pi\left(\left(l N_{s}+N_{g}\right) / N\right) \phi_{k}} \cdot X_{l}(k) \cdot H_{l(k)}+N_{l}(k)
\end{aligned}
$$

여기서, $\xi$ 는 샘플링 주파수 옵셋, $\alpha(\cdot)$ 는 샘플링 주파수 옵셋으로 인해 발생한 타이밍 옵셋의 신호 손 실 크기를 나타낸다. $e^{j 2 \pi\left(\xi \cdot N_{s} \cdot l\right) k / N}$ 은 샘플링 주파 수 옵셋에 의한 위상의 계수값을 의미하며, $X_{l}(k)$ 는 송 신된 $l$ 번째 OFDM 심볼에서 $k$ 번째 부반송파에 할당 된 데이터 심볼을 의미한다. $N, N_{g}, N_{s}$ 는 각각 $\mathrm{FFT}$ 크 기, 보호구간의 샘플수, 보호구간을 포함한 OFDM 심 볼주기의 샘플수를 나타내며, $N_{s}=N_{g}+N$ 이다. $\phi_{k}$ 는 일반적으로 반송파 $k$ 의 잔여 반송파 주파수 옵셋과 심볼 타이밍 옵셋으로 표현되나, 심볼 타이밍 옵셋이 0 이므로 잔여 주파수 옵셋 $\epsilon$ 으로 근사화 할 수 있다. $H_{l}(k)$ 와 $N_{l}(k)$ 는 각각 채널의 주파수 응답과 잡음을 의 미한다.

참조셀과 수신된 심볼의 상관을 이용하는 방식을 기법 1 이라 정의하며, 기법 1 은 다음과 같은 식으로 표현된다 ${ }^{[12]}$.

$$
\hat{l_{1}}=\underset{l_{1}}{\operatorname{argmax} \max }\left|\sum_{k=1}^{N_{R C}} R_{l_{1}}\left(P_{R C}[k]\right) \cdot X_{l_{1}}^{*}\left(P_{R C}[k]\right)\right|
$$

여기서, $l_{1}=0,1,2, \cdots, S_{n}-1$ 이며, $S_{n}$ 은 프레임 당 OFDM 심볼수를 의미한다. $P_{R C}[k]$ 는 $k$ 번째 참조셀 의 위치를, $R_{l}\left(P_{R C}[k]\right)$ 는 수신된 $l$ 번째 심볼의 $k$ 번째 참 조셀을, $X\left(P_{R C}[k]\right)$ 는 송신된 $k$ 번째 참조셀, 즉 이미 알 고 있는 참조셀을 의미한다. $N_{R C}$ 는 $0 \sim 4.5 \mathrm{kHz}$ 대역 의 모든 참조셀의 수를 의미한다.

식 (2)의 분석을 위해 식 (1)을 식 (2)에 대입하여 정리하면 다음과 같다.

$$
\begin{aligned}
\hat{l_{1}} & =\underset{l_{1}}{\arg \max } \frac{N-\xi \cdot N_{s} \cdot l_{1}}{N} \cdot e^{j 2 \pi\left(l_{1} \cdot N_{s} / N\right) \epsilon} \\
& \left|\sum_{k=1}^{N_{R C}} e^{j 2 \pi\left(\xi \cdot N_{s} \cdot l_{1}\right) P_{R C}[k] / N} \cdot H_{l_{1}}\left(P_{R C}[k]\right)\right| \\
& \underset{l_{1}}{\arg \max } \beta_{l_{1}} \cdot\left|\Gamma_{l_{1}}\right|
\end{aligned}
$$

여기서 $\beta_{l_{1}}=\frac{N-\xi \cdot N_{s} \cdot l_{1}}{N} \cdot e^{j 2 \pi\left(l_{1} \cdot N_{s} / N\right) \epsilon}$ 이며 $\Gamma_{l_{1}}=\sum_{k=1}^{N_{R C}} e^{j 2 \pi\left(\xi \cdot N_{s} \cdot l_{1}\right) P_{R C}[k] / N} \cdot H_{l_{1}}\left(P_{R C}[k]\right)$ 이다. $\beta_{l_{1}}$ 에서 잔여 주파수 옵셋의 값 $(\epsilon)$ 과 샘플링 주파수 옵셋 
은 매우 작은 값(ppm단위)으로 $\xi \ll 1$ 이고, 따라서 $\beta_{l_{1}} \approx 1$ 로 근사화 된다. 이를 수식 (3)에 적용하면 다 음과 같다.

$$
\hat{l_{1}} \approx \underset{l_{1}}{\arg \max }\left|\Gamma_{l_{1}}\right|
$$

$\mathrm{DRM}$ 에서는 참조셀이 비주기적이며, 불규칙적으로 배치되어 있으므로 $\Gamma_{l_{1}}$ 에서 $P_{R C}[k]$ 는 전체 FFT 영역 에 분포될 수 있어 샘플링 주파수 옵셋의 영향을 크게 받는다. 그리고 $\left|\sum_{k=1}^{N_{R C}} H_{l_{1}}\left(P_{R C}[k]\right)\right|$ 의 크기에 의해 $l_{1}$ 이 결정되며 $H_{l_{1}}\left(P_{R C}[k]\right)$ 는 $E\left[H_{l_{1}}\left(P_{R C}[k]\right)\right]=0$ 이고 WSS(Wise-Sense Stationary) 과정이므로 $N_{R C}$ 가 증 가할수록 $\left|\sum_{k=1}^{N_{R C}} H_{l_{1}}\left(P_{R C}[k]\right)\right|$ 는 작은 값이 되어 프레임 검출 성능이 저하된다.

수식 (3)에서 성능을 향상시키기 위해서는 $\Gamma_{l_{1}}$ 의 값 을 크게 해야 하는데, 이를 위해 인접 참조셀 사이의 채널 주파수 응답 변화가 거의 없다는 가정하에 (즉, $\left.H_{l}(k) \approx H_{l}(k+1)\right)$ 수신 참조셀의 인접 참조셀간 상 관 기법을 사용할 수 있다. 기법 2는 차동 상관 기법 으로 수신된 참조셀과 바로 인접한 참조셀의 상관 관 계를 구하는 방식이며 다음 식으로 표현할 수 있다.

$$
\hat{l_{2}}=\underset{l_{2}}{\operatorname{argmax}}\left|\begin{array}{l}
\sum_{k=1}^{N_{R C}-1} R_{l_{2}}\left(P_{R C}[k]\right) \\
\cdot R_{l_{2}}^{*}\left(P_{R C}[k+1]\right) \cdot e^{j 2 \pi \theta_{\text {diff }}(k)} \mid
\end{array}\right|
$$

여기서, $e^{j 2 \pi \theta_{d i f f}(k)}$ 는 인접한 참조셀들의 위상 차이 를 의미하며, 다음과 같이 정의된다.

$$
e^{j 2 \pi_{\text {diff }}(k)}=\angle X_{l_{2}}^{*}\left(P_{R C}[k]\right) \cdot X_{l_{2}}\left(P_{R C}[k+1]\right)
$$

기법 2의 방식은 참조셀과 바로 인접한 참조셀의 간격이 작기 때문에 위상변화의 폭도 상대적으로 작 은 값을 갖게 된다. 수신된 참조셀만을 좀 더 자세히 분석하면 다음과 같다.

$$
\begin{aligned}
& R_{l_{2}}\left(P_{R C}[k]\right) \cdot R_{l_{2}}^{*}\left(P_{R C}[k+1]\right) \\
& =\left(\frac{N-\xi \cdot N_{s} \cdot l_{2}}{N}\right)^{2} e^{j 2 \pi\left(\xi \cdot N_{s} \cdot l_{2}\right)\left(P_{R C}[k]-P_{R C}[k+1]\right) / N} \\
& \cdot e^{j 2 \pi\left(l_{2} \cdot N_{s} / N\right) \epsilon} \cdot X_{l_{2}}\left(P_{R C}[k]\right) \cdot X_{l_{2}}\left(P_{R C}[k+1]\right) \\
& \cdot H_{l_{2}}\left(P_{R C}[k]\right) \cdot H_{l_{2}}^{*}\left(P_{R C}[k+1]\right)
\end{aligned}
$$

수식 (7)에서 $X_{l_{2}}^{*}\left(P_{R C}[k]\right) \cdot X_{l_{2}}\left(P_{R C}[k+1]\right)$ 은 이 미 알고 있는 참조셀 신호임으로 $e^{j 2 \pi \theta_{\text {diff }}(k)}$ 를 곱하 여 제거할 수 있으며, 그 결과는 다음과 같다.

$$
\begin{aligned}
& R_{l_{2}}\left(P_{R C}[k]\right) \cdot R_{l_{2}}^{*}\left(P_{R C}[k+1]\right) \cdot e^{j 2 \pi_{d f f}(k)} \\
& =\left(\frac{N-\xi \cdot N_{s} \cdot l_{2}}{N}\right)^{2} e^{j 2 \pi\left(\xi \cdot N_{s} \cdot l_{2}\right)\left(P_{R C}[k]-P_{R C}[k+1]\right) / N} \\
& \cdot e^{j 2 \pi\left(l_{2} \cdot N_{s} / N\right) \epsilon} \cdot H_{l_{2}}\left(P_{R C}[k]\right) \cdot H_{l_{2}}^{*}\left(P_{R C}[k+1]\right)
\end{aligned}
$$

수식(8)을 수식(5)에 대입하면 아래와 같이 최종적 인 프레임 검출 결과를 얻을 수 있다.

$$
\begin{aligned}
\hat{l_{2}} & =\underset{l_{2}}{\operatorname{argmax}}\left(\frac{N-\xi \cdot N_{s} \cdot l_{2}}{N}\right)^{2} \\
& e^{j 2 \pi\left(l_{2} \cdot N_{s} / N\right) \epsilon}\left|\sum_{k=1}^{N_{R C}} e^{j 2 \pi\left(\xi \cdot N_{s} \cdot l_{2}\right)\left(P_{R C}[k]-P_{R C}[k+1]\right) / N}\right| \\
& =\underset{l_{2}}{\operatorname{argmax}} \beta_{l_{2}} \cdot \mid \Gamma_{l_{2}}\left(P_{R C}[k]\right) \cdot H_{l_{2}}^{*}\left(P_{R C}[k+1]\right)
\end{aligned}
$$

여기서 $\beta_{l_{2}}=\left(\frac{N-\xi \cdot N_{s} \cdot l_{2}}{N}\right)^{2} \cdot e^{j 2 \pi\left(l_{2} \cdot N_{s} / N\right) \epsilon}$ 이며 $\Gamma_{l_{2}}=\sum_{k=1}^{N_{R C}-1} e^{j 2 \pi\left(\xi \cdot N_{s} \cdot l_{2}\right)\left(P_{R C}[k]-P_{R C}[k+1]\right) / N} \cdot H_{l_{2}}\left(P_{R C}[k]\right)$ - $H_{l_{2}}^{*}\left(P_{R C}[k+1]\right)$ 이다. $\beta_{l_{2}}$ 에서도 마찬가지로 잔여 주파수 옵셋의 값 $(\epsilon)$ 과 샘플링 주파수 옵셋은 매우 작 은 값(ppm단위)으로 $\xi \ll 1$ 이고, 따라서 $\beta_{l_{2}} \approx 1$ 로 근 사화 된다. 이를 수식 (9)에 적용하면 다음과 같다.

$$
\hat{l_{2}} \approx \underset{l_{2}}{\operatorname{argmax}}\left|\Gamma_{l_{2}}\right|
$$

수식 (9)을 살펴보면 기법 1 의 프레임 검출 수식 (3)의 $P_{R C}[k]$ 과 기법 2 의 수식 (9)에서 $P_{R C}[k]-$ $P_{R C}[k+1]$ 부분이 차이가 있음을 알 수 있다. 기법 1 의 $P_{R C}[k]$ 은 전체 $\mathrm{FFT}$ 영역에 참조셀의 위치에 따라 샘 플링 주파수 옵셋에 영향을 받고, 기법 2의 $P_{R C}[k]$ $P_{R C}[k+1]$ 은 참조셀과 인접한 참조셀의 차이만큼만 샘 플링 주파수 옵셋에 영향을 받게 되므로 기법 2의 방식 이 샘플링 주파수 옵셋에 적게 영향을 받는다. 또 다른 차이점은 $\Gamma_{l_{1}}$ 의 $H_{l_{1}}\left(P_{R C}[k]\right)$ 과 $\Gamma_{l_{2}}$ 의 $H_{l_{2}}\left(P_{R C}[k]\right)$. $H_{l_{2}}^{*}\left(P_{R C}[k+1]\right)$ 이다. $\Gamma_{l_{2}}$ 의 $H_{l_{2}}\left(P_{R C}[k]\right) \cdot H_{l_{2}}^{*}\left(P_{R C}[k+1]\right)$ 은 $\Gamma_{l_{1}}$ 의 $H_{l_{1}}\left(P_{R C}[k]\right)$ 와 달리 평균값이 0 보다는 큰 값을 항상 가지므로 기법 1 보다 우수한 성능을 가짐 
을 알 수 있다.

정수배 주파수 옵셋의 추정은 식(2)와 식(4)에서 $P_{R C}[k]=P_{R C}[k]+\mathrm{m}$ 이고, 그때 상관값이 최대가 되 는 $\mathrm{m}$ 을 구하여 추정할 수 있다. 이 경우도 프레임 검 출과 동일한 과정을 수행하여 동일한 성능 분석 결과 를 얻을 수 있다.

\section{V. 모의실험}

본 절에서는 모의실험을 통해 DRM 수신 신호로부 터 초기 샘플링 주파수 옵셋을 추정하는 과정에서 어 느 정도의 시간이 소요되는지 알아보고, 기법 1 과 기 법 2의 초기 샘플링 주파수 옵셋에 따른 프레임 검출 성능 비교를 통해 본 논문에서 제안한 고속 동기화 구 조에 적합한 방식을 선정한다.

먼저 샘플링 주파수 옵셋 추정 및 보상시 필요한 심볼수를 측정 하였다. 샘플링 주파수 추정 및 보상 부분은 [10]에서 제시한 피드백(Feedback) 구조를 사 용하였으며, 표 2와 같은 조건하에서 모의실험을 수행 하였다. 피드백시 안정정인 추적을 위하여 루프게인 (Loop Gain)은 1/4을 적용하였다.

그림 7은 $\mathrm{DRM}$ 모드 $\mathrm{B}$ 에서 초기 샘플링 주파수 옵 셋이 $100 \mathrm{ppm}, 50 \mathrm{ppm}, 10 \mathrm{ppm}$ 인 경우 $\mathrm{OFDM}$ 심볼

표 2. 초기 샘플링 주파수 옵셋의 추정 및 보상 실험 조건

\begin{tabular}{|l|l|}
\hline \multicolumn{1}{|c|}{ 동작 블럭 } & \multicolumn{1}{c|}{ 모의실험 조건 } \\
\hline \multirow{3}{*}{ Pulse Shaping Filter } & Raised Cosine Filter \\
\cline { 2 - 2 } & Roll Off Factor : 0.3 \\
\cline { 2 - 2 } & 128 OverSampling \\
\hline \multirow{2}{*}{ Channel } & AWGN Channel \\
\cline { 2 - 2 } & SNR : OdB \\
\hline Loop Gain & $1 / 4$ \\
\hline
\end{tabular}

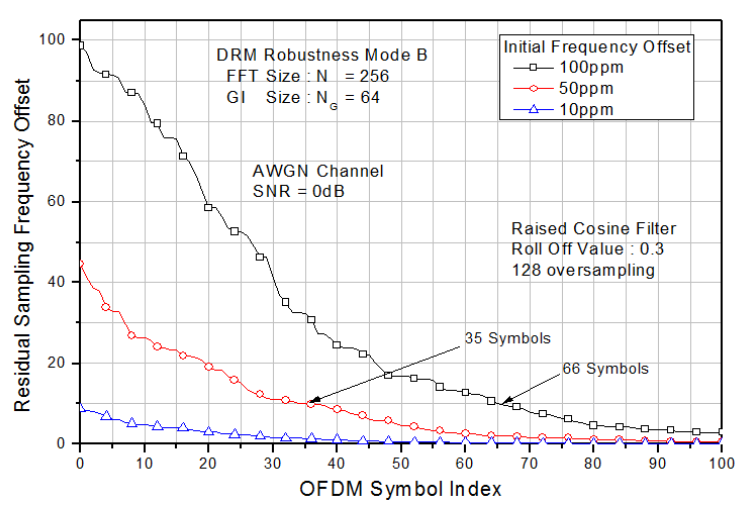

그림 7. 샘플링 주파수 옵셋 추정 및 보상 시 관찰되어야 하는 심볼수
수에 따른 샘플링 주파수 옵셋 추정 오차를 보여준다. 그림에서 알 수 있듯이 샘플링 주파수 옵셋이 증가할 수록 추정 및 보상에 필요한 심볼수가 크게 증가한다. 표 3은 초기 샘플링 주파수 옵셋이 $100 \mathrm{ppm}, 50 \mathrm{ppm}$, $10 \mathrm{ppm}$ 인 경우 $50 \mathrm{ppm}, 10 \mathrm{ppm}, 5 \mathrm{ppm}$ 의 오차 범위 로 추정 및 보상하기 위해 관찰해야 하는 심볼수 결과 를 보여준다.

표 3에서 볼 수 있듯이 초기 샘플링 주파수 옵셋이 $100 \mathrm{ppm}$ 인 경우, 추정 및 보상 과정을 통해 $50 \mathrm{ppm}$ 까지 보상하기 위해 필요한 관찰 심볼수는 28 개이고, $5 \mathrm{ppm}$ 까지 보상할 경우, 79개의 심볼수를 관찰해야 한다. DRM 모드 B인 경우, 유효 심볼 구간이 26.66 $\mathrm{ms}$ 이므로 $26.66 \mathrm{~ms}$ 에 관찰 심볼수를 곱한 시간만큼 제안된 방식이 기존 방식보다 초기 동기화에 소요되 는 시간을 단축 할 수 있다. 보상 옵셋 $(\mathrm{ppm})$ 의 목표는 각 수신기에서 요구되어지는 성능 지표에 따라 결정 된다.

다음으로는, 샘플링 주파수 옵셋이 존재하는 경우 에 프레임 검출 및 정수배 옵셋 추정 방식의 성능을 분석하였다. 또한, 모의실험에 사용한 채널환경은 $\mathrm{DRM}$ 규격에 정의된 표 4 와 같다. 채널 1 은 백색잡음 (AWGN) 채널이며, 채널 2는 다중경로를 갖는 라이 시안(Rician)채널이다 ${ }^{[1]}$.

그림 8 과 그림 9는 각각 채널 1 과 채널 2 에서 기법 1 과 기법 2의 샘플링 주파수 옵셋에 따른 프레임 검출 실패 확률을 나타낸다.

그림 8을 보면 AWGN 환경에서는 기법 1을 사용

표 3. 샘플링 주파수 옵셋에 따른 옵셋 보상을 위해 필요 한 심볼수

\begin{tabular}{|r|c|c|c|}
\hline $\begin{array}{r}\text { 초기 샘플링 } \\
\text { 주피수 오차 }\end{array}$ & $10 \mathrm{ppm}$ & $50 \mathrm{ppm}$ & $100 \mathrm{ppm}$ \\
$\begin{array}{r}\text { 잔류샘플링 } \\
\text { 주파수 오차 }\end{array}$ & & & \\
\hline $50 \mathrm{ppm}$ & & 35 & 66 \\
\hline $10 \mathrm{ppm}$ & & 48 & 79 \\
\hline $5 \mathrm{ppm}$ & 12 & 47 \\
\hline
\end{tabular}

표 4. 모의 실험을 위한 채널 프로파일

\begin{tabular}{|l|c|c:c|}
\hline & 채널 1 & \multicolumn{2}{|c|}{ 채널 2} \\
\hline Number of Path & 1 & \multicolumn{2}{|c|}{2} \\
\hline Delay & 0 & 0 & $1 \mathrm{~ms}$ \\
\hline Path Gain(dB) & 1 & 1 & 0.5 \\
\hline Doppler Shift & 0 & 0 & 0 \\
\hline Doppler Spread & 0 & 0 & $0.1 \mathrm{~Hz}$ \\
\hline
\end{tabular}




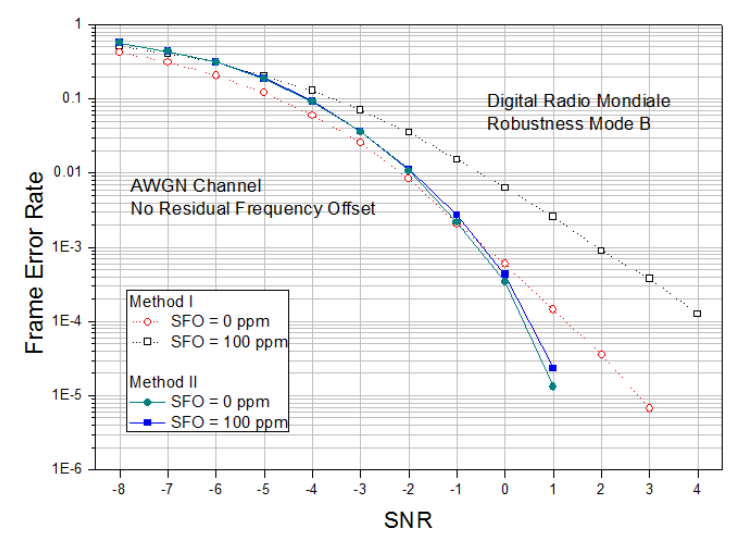

그림 8. 샘플링 주파수 옵셋에 따른 프레임 검출 실패 확률 모의실험 결과 (채널 1)

할 경우, 샘플링 주파수 옵셋이 $0 \mathrm{ppm}$ 에서 $100 \mathrm{ppm}$ 으로 증가할 때 샘플링 주파수 옵셋 영향으로 인한 성 능 저하가 발생한다. 특히 SNR이 증가할수록 성능 저 하가 크게 나타난다. 하지만 기법 2인 경우는 샘플링 주파수 옵셋이 증가하여도 프레임 검출 성능 저하가 미미하므로 샘플링 주파수 옵셋의 영향이 적음을 알 수 있다.

그림 9는 다중 경로 채널(채널 2)에서의 프레임 검 출 성능을 보여주는데, 기법 1 은 샘플링 주파수 옵셋 의 증가에 따른 성능 저하가 크고, 기법 2는 성능 저 하가 미미하다는 결과는 $\mathrm{AWGN}$ 의 경우와 유사하다. 그러나 AWGN과 달리 기법 1은 SNR 증가에 따라 성능 차이가 증가하지 않고 일정하게 나타난다. 또한, 기법 2는 높은 SNR에서 에러 플로어(floor)가 발생하 며, $-2 \sim 1.5 \mathrm{~dB}$ 이하에서 방식 1 에 비해 큰 오류를 갖는다. 이는 기법 2에서 사용하는 동일 심볼내 인접 참조셀간 차동 상관에서 인접한 두 개의 참조셀 주파 수응답과 잡음 차이가 포함되기 때문이다. 그러나 $\mathrm{SNR}$ 이 약 $0 \mathrm{~dB}$ 이상인 경우에 기법 2가 여전히 우수 한 검출 성능을 보이므로 기법 2 가 고속 동기화에 적

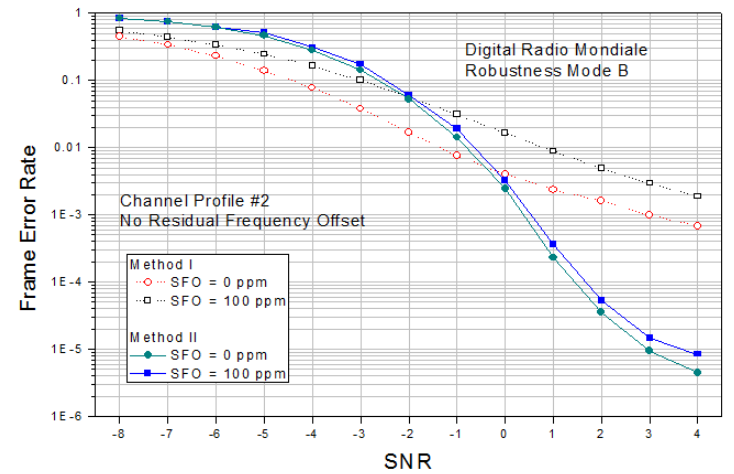

그림 9. 샘플링 주파수 옵셋에 따른 프레임 검출 실패 확률 모의실험 결과 (채널 2)
합하다고 할 수 있다.

\section{VI. 결 론}

본 논문에서는 DRM 시스템에서 요구되는 고속 동 기화 과정을 수행할 수 있는 방식을 제안하였다. 기존 동기화 방식은 초기 샘플링 주파수 옵셋 추정 및 보상 으로 인해 초기 동기화 과정이 길어진다. 이를 위해 초기 샘플링 주파수 옵셋 추정과 보상 부분을 FFT 전 단에서 생략함으로 동기화 시간을 단축시킬 수 있다. 또한, 샘플링 주파수 옵셋이 포함된 복조 심볼로부터 프레임 검출 옵셋을 추정하기 위해 참조셀에 상관 알 고리즘을 적용해 보고 그 성능을 분석하여 샘플링 주 파수 옵셋에 강한 상관 알고리즘을 선정하였다. 선정 된 참조셀 간 차동 상관 기법을 사용할 경우 초기 샘 플링 주파수 옵셋에 영향에 강인함을 프레임 검출 모 의실험을 통해 확인하였고, 제안된 고속 동기화 구조에 적합한 방식임을 제시하였다. 제안된 고속 동기화 방식 은 샘플링 주파수 옵셋 영향에 강인한 방식으로 DRM 수신기 구현시 중요한 요소기술로 사용될 수 있다.

\section{참 고 문 헌}

〔1] ETSI ES 201 980, V 3.1.1, Digital Radio Mondiale (DRM); System Specification, Aug. 2009.

[2〕 S. J Kim, K. W. Park, S. H. Park, K. W. Kwon and J. H. Paik, "An effective frame detection and FFT window point tracking algorithm for digital radion mondiale receivers," Proc. ICCE 2009, pp.1-2, Jan. 2009.

[3] V. Fischer and A. Kurpiers, "Frequency synchronization strategy for a PC-based DRM receiver," Proc. APCCS 2004, pp.989-992, Dec. 2004.

[4] M. M. Freda, J. F. Weng, and T. Le-Ngoc, "Joint channel estimation and synchronization for OFDM systems," Proc. IEEE VTC, Vol.3, pp.1673-1677, Sep. 2004.

[5] J. J. van de Beek, M. Sandell, and P. O. Borjesson, "ML estimation of time and frequency offset in OFDM systems," IEEE Trans. Commun., Vol.45, No.7, pp.1800-1805, July 1997.

[6] F. Hofmann, C. Hansen, and W. Schafer, 
"Digital Radio Mondiale(DRM) digital sound broadcasting in the AM bands," IEEE Trans. Broad., vol. 49, no. 3, pp. 319-328, Sep. 2003.

[7] F. Classen and H. Meyr, "Frequency synchronization algorithms for OFDM systems suitable for communication over frequency selective fading channels," Proc. of IEEE VTC, pp.1655-1659, June 1994.

[8] T. Pollet, "The BER performance of OFDM systems using nonsynchronized sampling," Proc. of GLOBCOM'94, pp.253-257, Dec. 1994.

[9] M. Speth, S. A. Fechtel, G. Fock, and H. Meyr, "Optimum receiver design for wireless broad-band systems using OFDM-Part I," IEEE Trans. Commun., Vol.47, No.11, pp.1668-1677, Nov. 1999.

[10] T. Pollet and M. Peeters, "Synchronization with DMT modulation," IEEE Communi. Mag., Vol. 37, No.4, pp.80-86, Apr. 1999.

[11] M. Speth, S. A. Fechtel, G. Fock, and H. Meyr, "Optimum receiver design for OFDM-based broadband transmission-Part II: A case study," IEEE Trans. Communi., Vol.49, No.4, pp.571578, Apr. 2001.

[12] H. Nogami and T. Nagashima, "A frequency and timing period acquisition technique for OFDM systems," Proc. IEEE PIMRC, pp. 1010-1015, Sep. 1995.
권 기 원 (Kwon $\mathrm{Ki}$ Won)

정회원

1997년 2월 광운대학교 컴퓨터

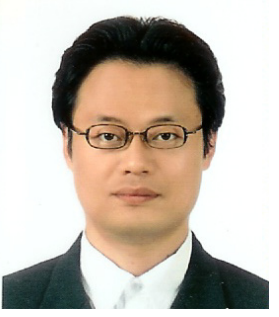
공학과(학사)

1999년 2월 광운대학교 컴퓨터 공학과(석사)

2011년 8월 중앙대학교 전자전 기공학부 박사

1999년 2월 현재 전자부품연 구원 책임연구원

<관심분야> 디지털통신, OFDM 모뎀 설계, 방송통 신융합시스템

조 용 수 (Yong Soo Cho) 종신회원

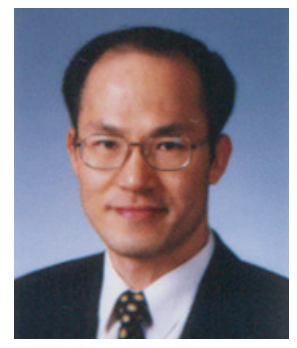

1984년 2월 중앙대학교 전자공 학과(학사)

1987년 2월 연세대학교 전자공 학과(석사)

1991년 2월 The University of

Texas at Austin 공학박사

1992년 3월 현재 중앙대학교 전자전기공학부 교수

2003년 8월 2007년 12월 TTA 휴대인터넷(와이브 로) 프로젝트 그룹 무선접속 실무반 의장 <관심분야> 디지털통신, MIMO-OFDM 모뎀 알고 리듬 개발 및 구현 